\title{
BIM-enabled Modular and Industrialized Construction in China
}

\author{
Peining $\mathrm{HU}$ and Jinyue $\mathrm{ZHANG} *$ \\ Department of Construction Management, Tianjin University \\ 92 Weijin Road, Tianjin, China, 300072 \\ *e-mail: jinyuezhang@tju.edu.cn
}

\begin{abstract}
The Chinese construction market is huge in terms of its size but facing many issues not matching its high speed development, such as low field productivity, unreliable quality, high resource and energy consumption, often safety accidents, and significant environment pollution. Those issues are mainly associated with the old fashion of construction method. The concept of industrialization of construction has been recognized since the establishment of the People's Republic of China, but did not get well developed until recently the industry is under the pressure of increasing labour cost and the demand of sustainable development. There was a surge of Building Information Modeling (BIM) application in last few years in China and the industry has seen lots of benefits of virtual design and construction. Integrating BIM technology into industrialization of construction is seen as a promising opportunity to improve the performance of modular and industrialized construction. This paper first reviews the history of industrialization of the Chinese construction industry and then discusses the recent BIM adoption in China. The approaches of using BIM to enable modular design and industrialized construction and installation in China are the main focus of this paper.
\end{abstract}

\section{KEYWORDS}

Modular construction; industrialization of construction; BIM; China

\section{INTRODUCTION}

The very high speed economic development in China in last ten years created a huge construction market; however, the Chinese construction industry is still characterized by low field productivity, unreliable quality, high resource and energy consumption, often safety accidents, and significant environment pollution. These problems are all related to the laborintensive nature of the Chinese construction industry as many projects employ cast-in-place construction approach (Zhao, 2014). There is a demand for an advanced construction approach to increase the overall performance of the industry.

Industrialization of construction has been receiving more and more attention in recent years in China after the first round of industrialization stagnated in the late 1980's. The industrialization of construction was first initiated in early 1950's during the first Five-Year Plan to meet the demand of facility reconstruction after the World War II and the Civil War (He and Chen, 2013). The first round of industrialization of construction focuses on the standardization of design, mass prefabrication of construction components, and 
mechanization of on-site construction. The mechanized and automated construction methods contributed a lot to urban development in next two decades. The concept of industrialization was faded away from 1980's along with Chinese economic reform. Fast economic development quickly raised the level of people's income, as well as the expectation on housing quality. Due to overly emphasizing the standardization of design, there were only few housing styles available. Limited technology level and construction materials at that age resulted in poor quality of prefabricated components, and thus the housing quality was low with issues of leaking and cracking. All of these did not satisfy the demand of a quickly expanding housing market. As a result, customized design and cast-in-place construction method have been dominating the construction market since 1990's (Gu, 2013).

The concept of industrialization was picked up again by the industry in last few years mainly because of two reasons. The first reason is that the lack of construction labour and increased labour cost in last few years. Along with the economic development, many new positions are available in service industry such as banks and restaurants which attract more young people because of the poor working condition and safety concerns in the construction industry. At the same time, the average salary of construction labor increased 31\% from 2000 to 2009, which is far more than the rate of construction material price and the average salary of all industries ( $\mathrm{Li}$ and $\mathrm{Liu}, 2015$ ). As a result, the Chinese construction industry is facing an aging labour structure, and in turn the industry seeks industrialization to minimize the need of field labour. The second reason is the demand on sustainable buildings and sustainable construction process. Traditional construction process consumes much energy and produces a lot of dust then modular construction which assembles prefabricated components on the site. Also, some new environment-friendly materials are more easily to be applied in prefabricated panels to meet the need for energy saving in operation stage.

There has been a surge on applying Building Information Modeling (BIM) in the Chinese construction industry since the Ministry of Housing and Urban Rural Development (MHURD) started to plan a series of national-level BIM standards (MHURD, 2011). With the help of an information-rich building model and data integration between business processes, BIM provides the industry with a great potential to promote the industrialization of construction and improve the performance of modular construction. This paper first investigates the history of industrialization in the Chinese construction industry in terms of its origination background, its potential and barriers to be overcome. Next, the adoption of BIM in China is studied to have an overview of BIM implementation in the world's largest construction market. The majority part of this paper discusses the approach of BIM-enabled modular and industrialized construction and installation.

\section{MODULAR AND INDUSTRIALIZED CONSTRUCTION IN CHINA}

The industrialization of Construction has gone through tree stages as shown in Table 1. The initialization stage ran from 1949 when the People's Republic of China was founded to 1978 which is the start year of Chinese economic reform. In order to meet the demand on housing after the Civil War, the experience on industrialization of construction from the Soviet Union was introduced to China. This stage emphasized the standardization of housing design, especially the standardization of precast concrete (PC) structural system. The early practices 
focused on PC slabs used on masonry structures and later PC wall panels were used on highrise apartment buildings. Along with the economic growth during Chinese economic reform, there is an increasing demand on both housing quality and quantity. Therefore, the focuses of the exploration stage are new supporting system like SAR by John Habraken (Bosma, 2000), new materials, the development of modular coordination standard, and modular kitchen and bathroom facilities. At the same time, a concept of housing industry was introduced to Chinese economic system which includes every sector serving housing planning, design, construction, renovation and decoration, maintenance, and operation management. The latest stage emphasizes sustainable aspects of construction projects, for example, energy saving, water conservation, land saving, material saving and environment protection. The leading company in this filed is Broad Homes that first developed integrated and modular bathroom with SUZUKI and then proposed clustering system for building structure, door, window, kitchen, bathroom, floor, HVAC, plumbing, and electricity. Wanke is the first and leading developer in China to practice industrialized apartment buildings and its focus is manufactured building structure by PC components.

Table 1: The history of China's Industrialization of Construction

\begin{tabular}{lll}
\hline Stages & Driven Forces & Focuses \\
\hline $\begin{array}{l}\text { Initialization } \\
(1949-1978)\end{array}$ & $\begin{array}{l}\text { Demand on massive } \\
\text { construction of housing and } \\
\text { industrial facilities }\end{array}$ & Construction productivity \\
$\begin{array}{l}\text { Exploration } \\
(1978-1998)\end{array}$ & $\begin{array}{l}\text { Demand on housing quantity } \\
\text { and quality }\end{array}$ & $\begin{array}{l}\text { Labour productivity, housing quality, } \\
\text { construction speed }\end{array}$ \\
$\begin{array}{l}\text { Transition } \\
(1998-\text {-now })\end{array}$ & Multiple factors & $\begin{array}{l}\text { Labour productivity and safety, } \\
\text { building quality, construction cost, } \\
\text { sustainability }\end{array}$ \\
\hline
\end{tabular}

Every year, there are more than 2 billion square meters of new construction in China, which accounts for more than $50 \%$ of the total new construction in the world. However, the industrialization of construction in China isn't well recognized by the market - less than $1 \%$ of the new construction is built in an industrialized approach. There are several barriers. Firstly, there lacks the financial support from Chinese government. The government encourages the industrialization of construction only at police talks but no actual capital investment or tax-saving for companies developing industrialized facilities or components. Secondly, some building codes lag behind the technology of industrialization and, in many cases, industrialized building projects need special review and approval just because some construction methods are beyond the regulation in current building codes. Thirdly, the administration of construction industry is not completely ready for industrialization process in many aspects, for example, component manufacturing, biding and tendering, and construction safety regulation. Fourthly, industrialized construction projects do not have attractive financial benefit. Every corporation is profit driven. Currently, the cost of industrialized building is higher than buildings delivered in a traditional method. For example, manufactured PC wall panels are more expensive than brick-mortar walls. Without proper intervention from government and practical economic benefit achieved by a matured business chain for cost-effective industrialization, it is not easy to convince companies to practice modular and industrialized construction. 
Fortunately, Chinese government has seen industrialization as the trend of the construction industry to meet the demand of sustainable development. The construction market will be continuously increasing in next two or three decades, and the new housing area in next thirty years will be $20-30$ billion square meters. The goal set by the Ministry of Housing and Urban Rural Development (MHURD) is that $50+\%$ of all housing projects $(60+\%$ affordable housing projects) should be built by industrialized construction by 2020 (MHURD, 2011).

\section{BIM ADOPTION IN CHINA}

The Chinese construction industry got to know the concept of B uilding Information Modeling (BIM) around 2002 and only few projects employed BIM until few years ago the benefits of BIM are commonly acknowledged by the majority of the industry. There is a surge of BIM application since 2012 when the MMHURD started to plan a series of national-level BIM standards. Although many projects has started to use BIM approach and most built environment professionals began to learn knowledge of BIM, the overall maturity of using BIM in China is at early level. Most application of BIM occurred in the design phase, especially in the early years of using BIM in China. The BIM use for cost and project management received more attention in last few years and now becomes a main focus of project owners (Feng, 2013).

The most mature application of BIM in China is clash detection and integration/optimization of building service systems. The most common way in which industry professionals collaborate with each other in a BIM project is that owner's representative, designers and general contractor collaborate through building information models in coordination meetings to analysis constructability issues and assess changes in terms of their impacts on cost and schedule (An and Zhou, 2014). A federated model is used to load several BIM models created by different parties into one software platform for coordination. Autodesk Navisworks is currently the market leader in China as a platform for federated model review. Glodon model checker GMC2013 is a similar software application made by Chinese BIM software vendor Glodon.

4D-BIM is a great way to improve construction efficiency by optimizing construction schedule ( $\mathrm{Li}$ and Qin, 2014). There are two types of 4D-BIM application in China. Most contractors just use 4D simulation to visualize a construction schedule planned in a traditional way. This level of 4D-BIM application can help in communicating schedule with involved parties but does not benefit a contractor too much in terms of construction efficiency. Some contractors use 4D-BIM to analyze construction schedule by comparing different schedule options in terms of site logistics and time-space coordination. Few contractors have started to use advanced 4D/5D-BIM software tools, for example, the flowline feature in VICO Office, to optimize construction schedule by reducing buffer time and lead time of construction activities.

The lack of BIM execution guidelines and the lack of BIM specialists are two significant challenges in China (Zhao, 2014). Along with the acknowledgement of BIM benefits, suddenly many construction projects have a demand of using BIM in last few years, but the 
industry has no time to systematically study and research a strategic and technical execution approach suitable for local projects. Many projects take peer projects or foreign BIM Execution Plans as references. At the same time, due to the large scale of Chinese construction market, there lacks BIM-capable professionals. Beside those managerial challenges, the lack of local BIM software tools is a technical challenge. Foreign BIM tools are not designed based on Chinese building codes and not follow local industry conventions. This makes the model hardly to be directly used for some technical analyses which involve local rules.

With the contentious efforts by the government and the industry, in next few years, the Chinese construction industry will definitely see a quick growth on using BIM technology to improve its overall performance. Along with the increasing attention on modular and industrialized construction, integrating BIM technology into industrialization of construction is seen as a promising opportunity to boom this market. Next section will discuss the way of using BIM to support modular and industrialized construction.

\section{BIM-ENABLED MODULAR DESIGN}

BIM-enabled modular design is based on the modularization of building components. The modular design has been applied to high-rise apartment buildings by Waike, the largest housing developer in China. This design method is more suitable for buildings having similar layout or unit assemblies such as affordable housing development. Due to the constraints on total area of a housing unit and the cost of each unit area, there are not too many choices on the layout of affordable housings, and the only difference is the decision on the number of units on a standard floor and the selection of the layout of a housing unit with limited customization on dimensions. BIM is used to support the parametric design at different module levels. The first level of modularization is the unit layout. The unit module is then disassembled into room level modules such as bathroom and kitchen. The next level of module includes building components such as wall panels or plumbing system, as shown in Figure 1 (Han et al., 2014).
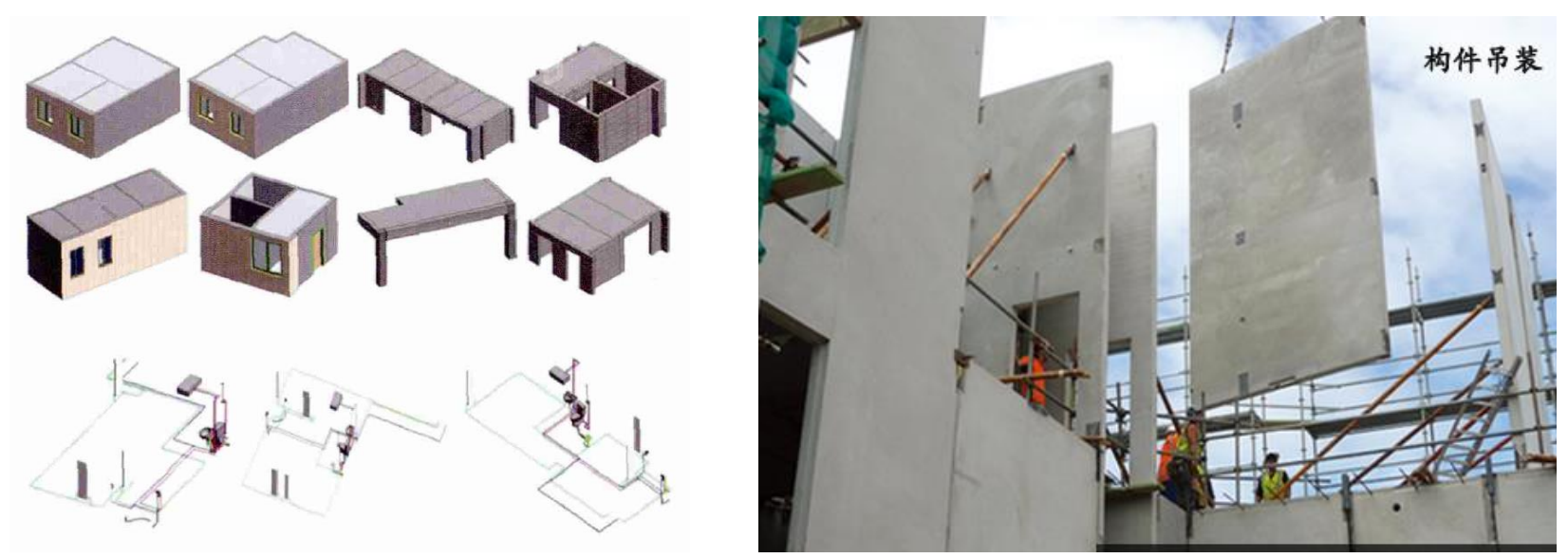

Figure 1: Modules at different level and the on-site erection of components

The design process starts by selecting a number of desired units based on their layouts from the Unit Layout Library (ULL) and then assembling a floor plan by customizing dimensions. 
After the architectural design is proposed, a structural engineer will create a structural model by selecting modules from Structural Module Library (SML) according to the architectural design and then send the structural model to mechanical software for analysis. At the same time, a MEP designer also takes the advantage of a library of MEP modules which are assemblies of a set of MEP components to conduct design for building service systems.

\section{BIM-ENABLED INDUSTRIALIZED CONSTRUCTION \& INSTALLATION}

The first application of BIM in industrialization of construction is clash detection and constructability analysis in pre-construction stage. There are several hundred or thousand prefabricated components in a PC building as such, by traditional approach of constriction drawing review and coordination meetings, it is hard to make sure that there is no conflict during on-site construction. Some conflicts, especially clashes caused by reinforcement bars or embedded parts in a PC components, are more difficult to deal with than cast-in-place construction. By developing digital models for each component and putting all models together in a virtual construction process, Shanghai Urban Construction Group (SUCG), the leading PC building construction company in China, has resolved many simple but repeated conflicts or constructability issues that may happen on-site in fabrication process.

A more attracting benefit to PC component manufacturers is that the BIM models of PC components provides the manufacturer with valuable data to support the integration of design, manufacturing, construction, and even operation/maintenance processes. Also, the data in a BIM model can also support the whole manufacturing process from material ordering, infactory logistics, packaging, stocking, and transporting to the construction site. SUCG established a BIM-data platform to support four systems: component design and detailing system, manufacturing management system, on-site construction management system, and remote monitoring system (Zhulong, 2014a). This platform largely improved project performance in quality, schedule, and cost.
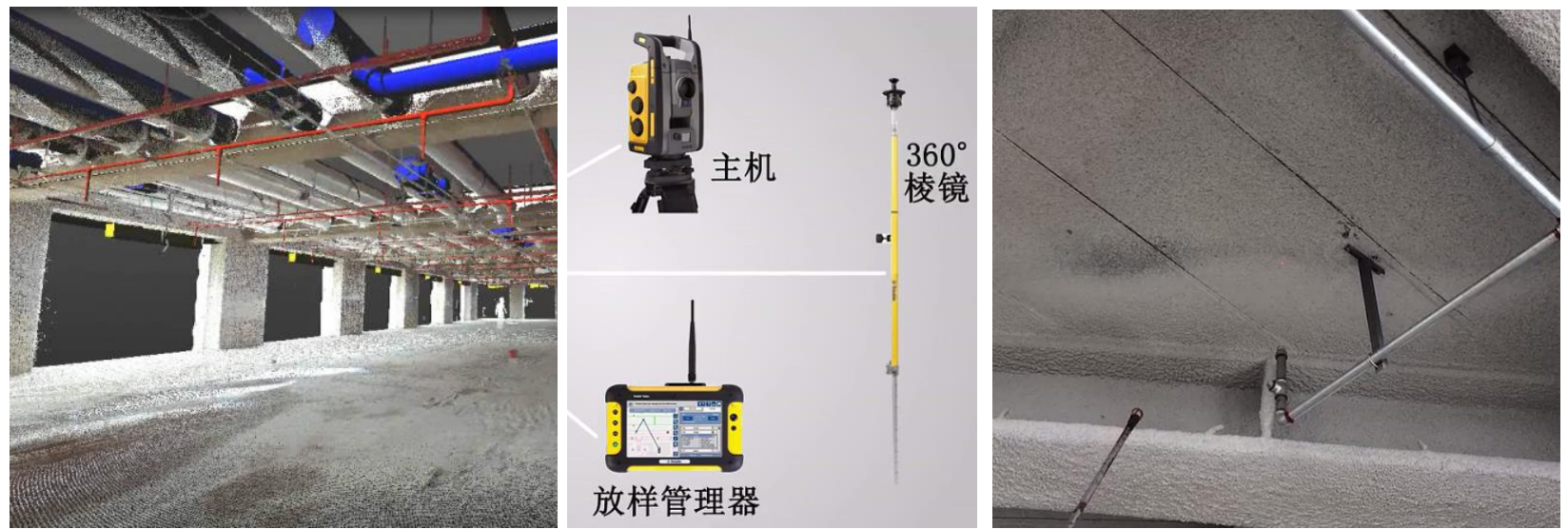

Figure 2: Point cloud model combined with robotic total station layout

Some large MEP contractors have begun to practice the concept of industrialized installation. BIM models provide the MEP contractor with accurate geometric information of service systems of a construction project, and system integration and coordination supported by model checkers such as Autodesk Navisworks and Solibri will solve the problem in the old 
days that system layout and sizes are not accurate. Although the design information of MEP system could be very accurate in BIM models, the physical installation condition normally is not as ideal as the model in the computer because the construction quality of concrete structures may vary. This is the issue faced by early practitioners who fabricate system components such as ducts and pipes in factories. Recently some sophisticated MEP contractors started to employ 3D laser scanning equipment to create as-built point cloud model of the structure system and then use it to calibrate the design model of MEP system to produces accurate fabrication drawings. This is the approach used by Pingan Tower project in Shenzhen, China. The MEP contractor also used robotic total station combined with BIM models to ensure fast and accurate layout of MEP systems, as shown in Figure 2 (Zhulong, 2014b).

\section{CONCLUSION}

The high speed economic development in China requires a healthy and sustainable construction industry to meet the big demand of civil and infrastructure facilities. After few decades of limited development in industrialization of construction, the large adoption of BIM has been seen an accelerator to boom modular and industrialized constriction in both technical and management fields. The recent practices in China has demonstrated innovations in BIM-enabled modular design, clash detection and constructability study by BIM models to facilitate fabrication process, manufacturing management by data retrieved from BIM models, and using 3D laser scanning technology to ensure accurate geometric information of MEP systems. Along the mature use of BIM in Chinese construction industry in the near future, more benefits of modular and industrialized construction will be unearthed, such as material saving, higher construction quality, shorter construction time, and safer working environment.

\section{REFERENCES}

An, B. and Zhou, X. (2014). "BIM application in Tianjin 117 project: a general contractor's perspective." Journal of Construction Quality. Vol. 2014(12).

Bosma, K. (2000). Housing for the Millions: John Habraken and the SAR. NAi Publishers.

Feng, Y. (2013). "The Roadmap of Hongye BIM Software." Proceedings of the $4^{\text {th }}$ Computing in Construction Summit, Shanghai, November 11-15, 2013.

Gu. M. (2013). "A discussion on the relation between industrialization of construction and economic development." Housing Industry. Vol. 2013(3).

Han, J., Zhang, D. and Zhao, Q. (2014). "BIM-based modular design approach for industrialization of housing construction." Architecture. Vol. 22.

He, L. and Chen, Y. (2013). "The present and future of industrialization of construction." Project Quality. Vol. 2013(2).

Li, F. and Liu, S. (2015). "The lack of construction labor in China and its impact." Construction Economics, Vol. 36(2), 18-21.

Li, J. \& Qin, G. (2014). "A study on 5D-BIM-based construction project cost control system." Journal of Construction Management Technology, Vol. 2014(5).

MHURD. (2011). Development Outline of Informatization in the Construction Industry 2011-2015. Located @ http://www.gov.cn/gongbao/content/2011/content_2010588.htm. Accessed on April 6, 2015.

Zhao, X. (ed.) 2014. A Report of Informatization in the Chinese Construction Industry: BIM Application and Development. China City Press. Beijing, China. 
Zhulong. (2014a). BIM Technology enables the industrialization of construction. Located @ http://wiki.zhulong.com/bim229/type231/topic722992_c.html. Accessed on April 6, 2015.

Zhulong. (2014b). Digital technology supports the construction of Pingan Tower. Located @ http://news.zhulong.com/read/detail198434.html. Accessed on April 6, 2015. 